\title{
Tracking political climate change: US policy and the human right to water
}

\author{
F. Sternlieb \& M. Laituri \\ Department of Geosciences, Colorado State University, USA
}

\begin{abstract}
The Paul Simon Water for the Poor Act of 2005 (PL 109-121) aims to "make access to safe water and sanitation to the developing countries a specific objective of the United States foreign assistance programs." Although the Act makes no mention of a right to water and sanitation (RTWS), but instead focuses on issues related to sustainability, equity, and affordability, the case to improve access to water and sanitation is eloquently stated. The United States' tactic mirrors the international approach to water: fragmented, multiple governing agencies managing narrow components, competing ideologies for water management, and confusing regulatory structures for legal water rights and water quality standards. Alternatively, this confusing context provides the foundation for innovative approaches to water solutions that include integrated water resource management, collaborative partnerships, and adaptable management strategies that are focused on place-based solutions and processes. This paper outlines a methodology to assess the Paul Simon Water for the Poor Act (WfP Act) by (1) tracking access to safe water and sanitation, (2) identifying water resources governance and management efforts for water productivity, and (3) including efforts to improve water security through increased cooperation on shared waters. Using a geographic information system (GIS), the outcomes will be classified by geographic extent and include projects that are country, regionally, or community-driven, have measureable results, and maximize impacts with specific emphasis on women and children. The Paul Simon Act is required to prepare an annual report to Congress that describes key activities and reforms. This information can be displayed spatially using a GIS. A comparative analysis will be designed by linking results from the WfP analysis to results of the UN's Millennium Development Goal (MDG) Joint Monitoring Programme for Water and Sanitation to initiate a global assessment of the RTWS.
\end{abstract}

Keywords: US Policy, right to water, GIS, IWRM, MDG. 


\section{Introduction}

Water is at the nexus of the critical issues of the twenty-first century: increasing population, deteriorating environments, and escalating climate change. In 2000, the UN Millennium Development Goals (MDGs) identified water for the poor as a key aim with the goal to reduce by half the proportion of the world's population lacking safe drinking water and basic sanitation by 2015. The Paul Simon Water for the Poor Act of 2005 (PL 109-121) (WfP Act) aims to "make access to safe water and sanitation to the developing countries a specific policy objective of the United States foreign assistance programs" [1]. This paper examines the WfP Act and its contribution to increase access to water and sanitation for people in the developing world. We will consider the following broad issue: how does the WfP Act operate as a catalyst to address international development issues with regard to the right to water and sanitation?

The United States' approach mirrors the international approach to water: fragmented, multiple governing agencies managing narrow components (e.g., river protection, groundwater monitoring, hydropower, flood control), competing ideologies for water management (e.g., neoliberal economic strategies, rightsbased approaches to resource access, large-scale structural solutions) and confusing regulatory structures for legal water rights and water quality standards. Alternatively, this confusing context provides the basis for innovative approaches to water solutions that include integrated water resource management, collaborative partnerships, adaptable management strategies, and are focused on place-based solutions and processes [1].

This paper will describe a methodology for tracking the outcomes of the WfP Act that addresses: (1) increased access to safe water and sanitation to improve human health for the poor in developing countries, (2) improved water resources governance and management that have increased water productivity, and (3) strengthened cooperation on shared waters that have led to improvements of water security [1]. These outcomes include projects that are country, regionally, or community-driven, have measurable results (i.e. population with increased access to water), maximize impacts with specific emphasis on women and children, builds upon previous work in the region, and leverages partnerships to expand US efforts.

The purpose of this study is to assess the relationship between poverty, human rights, and water resources based on the structure of environmental governance (i.e., WfP Act) using geospatial analysis and triangulation (Figure 1). Access to water and sanitation is inherently spatial, crossing natural and political boundaries and linking the global dimensions of water deprivation and poverty to local scales of the gendered divisions of water provisioning [3, 4]. Geospatial tools provide the means for database organization, storage and visualization of locations, and characteristics of WfP Act projects. Triangulation of poverty characteristics, human rights activities, and water resource governance will be used to assess the role of the WfP Act to address international development issues with regard to the right to water and sanitation. 


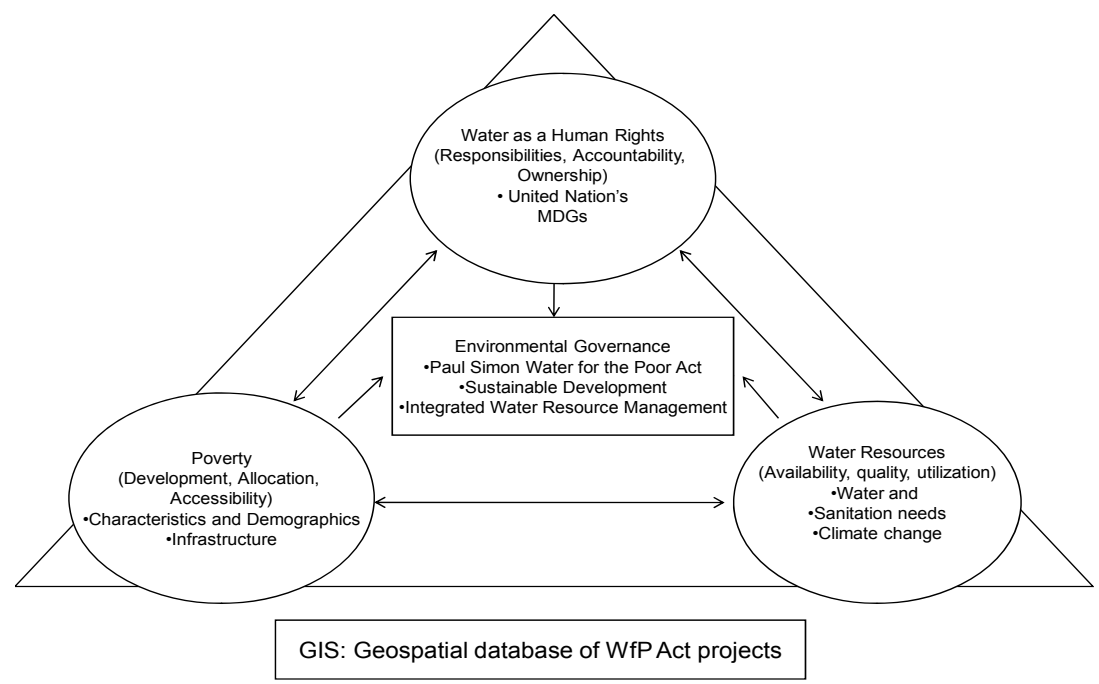

Figure 1: $\quad$ Triangulation map to assess the WfP Act.

\section{The global water challenge, poverty, and the WfP Act}

The WfP Act makes explicit reference to Target 10 of the United Nations Millennium Development Goals which is to reduce by half the proportion of people without access to safe drinking water by 2015 [1]. The WfP Act identifies the connection between access to safe water and sanitation to fighting hunger and poverty, gender equality, and improving the lives of slum dwellers. Situated to address global initiatives, the WfP Act amends the Foreign Assistance Act of 1961 and the Agricultural Trade Development and Assistance Act of 1954 making the provision of safe water and sanitation part of explicit US foreign policy.

The global water challenge has several components: continued water deprivation and lack of sanitation systems among the world's poor, human impacts on the world's freshwater systems, competing and confusing institutional arrangements, supply allocation across multiple uses, and global climate change [5]. The WfP Act states that over 1.1 billion people lack access to safe drinking water and that nearly 2.6 billion people lack access to basic sanitation. One of the major challenges in achieving the MDGs with regard to access to clean water and sanitation is improving the link between healthy ecosystems and healthy human systems. Access to potable water and sanitation has a profound impact on both a healthy environment and livelihoods [6, 7].

As defined by the UN Office of the High Commissioner for Human Rights, "poverty is a human condition characterized by the sustained or chronic deprivation of the resources, capabilities, choices, security, and power necessary for the enjoyment of an adequate standard of living and other civil, cultural, economic, political, and social rights" [8]. Generally such deprivation is 
experienced by marginalized people, specifically the poor and oppressed, women, children, and indigenous people - usually minorities. However Articles 1 and 2 of the Universal Declaration of Human Rights proclaimed by the United Nations General Assembly in 1948 states that "all human beings are born free and equal in dignity and rights without distinction of any kind, such as race, colour, sex, language, religion, political or other opinion, national or social origin, property, birth or other status" [9]. Expressing water as a human right emphasizes that universal access to sufficient water for basic needs is an absolute and non-negotiable priority [10].

Although the human right to water is not explicitly stated in the International Covenant on Economic, Social and Cultural Rights, "it provides an authoritative, but not a legally binding interpretation of the right to water" [10]. This Covenant was ratified by 151 countries. The right to water is inherently linked to poverty eradication. The connection is stated in the Plan of Implementation for the World Summit on Sustainable Development: "the provision of clean drinking water and adequate sanitation is necessary to protect human health and the environment" [11]. In addition, the Millennium Declaration names 2005-2015 the International Decade for Action, Water for Life. Goal 7, Target 3 of the MDGs aims to "halve by 2015 the proportion of the population without sustainable access to safe drinking water and basic sanitation" where "women shoulder the largest burden in collecting water" [12].

Despite the urgency to build sustainable infrastructure to deliver clean water, supply of fresh water resources have become highly variable due to climate change. Climate change effects also add stress to water supply and management systems $[5,13]$. Mismanagement and institutional partnerships that favour those who can afford associated costs of receiving clean water and sanitation contribute to the divide between the privileged and the poor. Independent of the modern and antiquated infrastructure in place to deliver water, the geography of water distribution inherently limits access and will continue to do so in the near and distant future. Wastewater management directly impacts the surrounding natural environment by reducing the quantity of polluted water discharged into the environment [14]. In addition, the environment has built-in mechanisms that naturally decontaminate polluted water where swamps, mangroves, and marshes act as natural filters. Understanding, identifying, and protecting the interactions within natural systems and the ecosystem services that afford humans clean, potable water is key to sustaining healthy livelihoods.

Emerging among the growing number of institutional arrangements surrounding international water policy are several different agendas: development assistance initiatives, conflict resolution management, debates about private/public water rights especially in the context of large dams, water marketing, the campaign to recognize water as a human right $[10,15-18]$, and transboundary water controversies [5]. Complex water governing structures are at the heart of the aid arena. Tracing the paradigmatic transition from top-down to bottom-up approaches, institutional cooperatives are now opting for building capacity and promoting empowerment through active participation. An example of a global cooperative is the Safe Drinking Water Alliance, a multi institutional 
private-public contract dedicated to increasing access to household drinking water [19]. Other approaches are the indigenous organization of natural resources based on common property resource management regimes [20-22], comanagement arrangements, [23] and ownership of a resource by a community [24].

The Centre for Strategic and International Studies [25], a scientific think tank in Washington D.C, drafted Global Water Futures: A roadmap for future U.S. Policy. This report on water issues was integral to shaping US foreign policy. The WfP Act was born through the triangulation of findings from this report and past policies such as the Foreign Assistance Act of 1961, the UNICEF and WHO statistics for poor people in developing countries [26] and historical US waterrelated development assistance [5].

The WfP Act was signed into law by President Bush in 2005. The Act makes access to water and sanitation in developing countries an explicit foreign policy objective of the US government, requiring the Secretary of State and the United States Agency for International Development (USAID) with other US agencies to implement policies. These policies are taking on forms that address the issue of water governance - the interaction between state authority, private management and markets, and voluntary participation by local stakeholders, international aid entities or civil society [27]. Of the 15 US agencies that participate in international water issues only three receive direct appropriations related to water in developing countries: USAID, the Millennium Challenge Corporation (MCC) (MCC was established in 2003 by Congress. The MCC's mission is to reduce global poverty through the promotion of sustainable economic growth.), and the Department of Defence. Other agencies, such as the Environmental Protection Agency, Peace Corps, and the US Army Corps of Engineers, provide technical expertise. The Consolidated Appropriations Act of 2008 allocated $\$ 300$ million for safe drinking water and sanitation projects to implement the WfP Act.

The State Department and USAID are required to prepare an annual report to Congress that tracks US progress with respect to achieving the WfP Act objectives. In addition, these two agencies are required to prepare reports on water for peace and security documenting efforts to promote programs that develop river basin, aquifer, and other watershed mechanisms for effective governance and cooperation. The annual reports on the WfP Act place the Act's objectives into broader development objectives of the US that include not only increased access to safe water and sanitation to improve human health, but improvements to water resource management and increased water productivity, as well as improved water security by strengthening cooperation on shared waters [28]. The State Department and USAID have prepared guidelines for projects and activities that will meet the requirements of the act in "Addressing Water Challenges in the Developing World: A Framework for Action" [28].

Key aspects of this framework are the water-related linkages to health, economic growth, democracy, and security goals of US foreign policy. As such, US foreign policy should be integrated and should focus on appropriate technology to enabling environments and human capacity [28]. One approach is 
Integrated Water Resources Management (IWRM), an adaptive management strategy of expert networks that intersect with government and nongovernmental stakeholders [5]. At the World Summit of Sustainable Development in Johannesburg, South Africa in 2002, the Global Water Partnership defined IWRM "as a process, which promotes the coordinated development and management of water, land and related resources in order to maximize the resultant economic and social welfare in an equitable manner without compromising the sustainability of vital ecosystems" [19].

USAID has written IWRM into the strategic international development plan which addresses five main goals: economic growth and agricultural development, democracy and good governance, human-capacity building through education and training, world population stabilization and human health protection, global environmental protection and long-term sustainability, and saving lives and reducing suffering associated with disasters [29]. As one of the implementing agencies for the WfP Act, USAID has launched ECO-Asia, a regional program that promotes improved access to clean water and sanitation among other goals [30]. It is through ECO-Asia that the US government uses IWRM to achieve both the national goals of the WfP Act and the international MDGs of the United Nations. A key component of the ECO-Asia projects are "twinning" or partnering public and private entities to better manage resources and broaden the "state-centric" emphasis of many IWRM activities [37].

To date, three reports on the WfP Act with supporting annexes have been submitted to Congress (http:/www.state.gov/g/oes/water/). These reports provide the basis for the development of a geospatial assessment of the outcomes of the WfP Act using triangulation.

\section{Analysis of the WfP Act using triangulation and GIS}

The purpose of combining GIS and triangulation is to track the political climate change surrounding water resources to better understand how social systems interact with the natural environment across spatial scales using the watershed as the unit of analysis. Using stream networks and drainage divides, the watershed can be scaled from local to continental levels intersecting with human land use patterns and governance structures. Geospatial analysis and triangulation can be used to assess the emerging projects of the WfP Act.

Triangulation is used to explain the connection and interaction between people and their environment in the context of water resources and its' availability, scarcity, variability, and vulnerability from multiple perspectives. The term is taken from a technique used in "land-surveying where knowing a single landmark only locates a position somewhere along a line in a direction from the landmark, whereas with two landmarks bearings can be taken in two directions and can locate the position at the intersection" [31]. Triangulation originally described a way of performing research analysis where more than one method of observation and more than one trait must be employed in order to validate the measurement process of any single concept [32]. For our purposes, we have chosen to examine poverty, water resources, and human rights to assess 
if the WfP Act has increased access to clean water and sanitation for the poor and marginalized people in developing countries.

The watershed is a complex system of biological, physical, and chemical characteristics that operate on a temporal and spatial scale. A watershed system is defined here as a geologically defined area with topographic boundaries, in which all surface and underground waterways flow toward one direction and drain in a common basin where water and all of its physical, chemical, and biological properties are collected [33-35]. A key aspect of using the watershed as the unit of analysis is the ability to recognize the dynamic nature of the boundary. The watershed can be defined at multiple nested spatial scales to conduct cross-scale analysis of higher orders of government activity (Figure 2) [36]. This is particularly important for addressing transboundary water issues where scale is critical to understanding water flow, delivery, impoundment, and local impacts.

The intersection of the watershed with environmental governance occurs in land use designations and activities, hydrologic impacts due to human activity, and jurisdictional boundaries that often do not mimic the natural environment and may lead to disjunctive biophysical processes. Social inputs to biophysical processes include both point and non-point sources of pollution and waste from industrial, agricultural, and municipal activities as well as resource extraction $[33,35]$. Ecological outcomes from social inputs may result in atmospheric deposition of industrial byproducts, eutrophication in freshwater systems leading to algal blooms and fish kills, excess sedimentation due to forest removal and overuse of marginal lands, and bacterial and chemical pollutants contaminating sources of drinking water which in turn impacts the growth and development of human systems [24]. The aims of the WfP Act will result in increased access to water and sanitation that will necessarily intersect with the landscape creating unintended consequences due to water redistribution and allocation.

GIS is an important tool for understanding, analyzing, and communicating the intersection and juxtaposition of spatial data with specific application to understanding relationships between watersheds, land use, political jurisdictions, and ecosystems. Boundaries are imposed top-down by governments (political jurisdictions), scientists (ecological zones), and sometimes in conjunction with determining resource or water management units. Watersheds, ecoregions, and communities of place are often used as the unit of analysis with the recognition that none is perfect in addressing the complex landscape of climate change, adaptability, and water resources. Different units of analysis represent a kaleidoscope of priorities for how the landscape is used and managed; but it is the intersection of these boundary units that we examine through an assessment of the WfP Act. GIS is used to conduct an overlapping patchwork analysis [37] providing a spatial representation by which to examine our boundaries of watersheds, water delivery networks, urban and peri-urban areas, and rural communities.

Baseline data on physical, ecological, political, and social boundaries will be organized into a geographic information system and organized into a nested spatial hierarchy reflecting local, regional, and global scales. Boundaries 
(watersheds, eco-regions, and land use) and networks (streams, roads, and water supply and sanitation networks) will be overlaid to assess spatial relationships, such as proximity, coincidence, and distance between boundaries. Overlaying multiple boundaries create a patchwork layer from which to measure perimeters and network intersections where edge effects can be identified based upon boundary-type characteristics. This process will focus on the following: 1) where do all boundaries intersect in terms of the geography of the available water resources, 2) do boundaries contribute to conflict or cooperation, 3) which institutions manage the resources and where are the management boundaries located, and 4) what are the demographics of the population within the various boundaries?

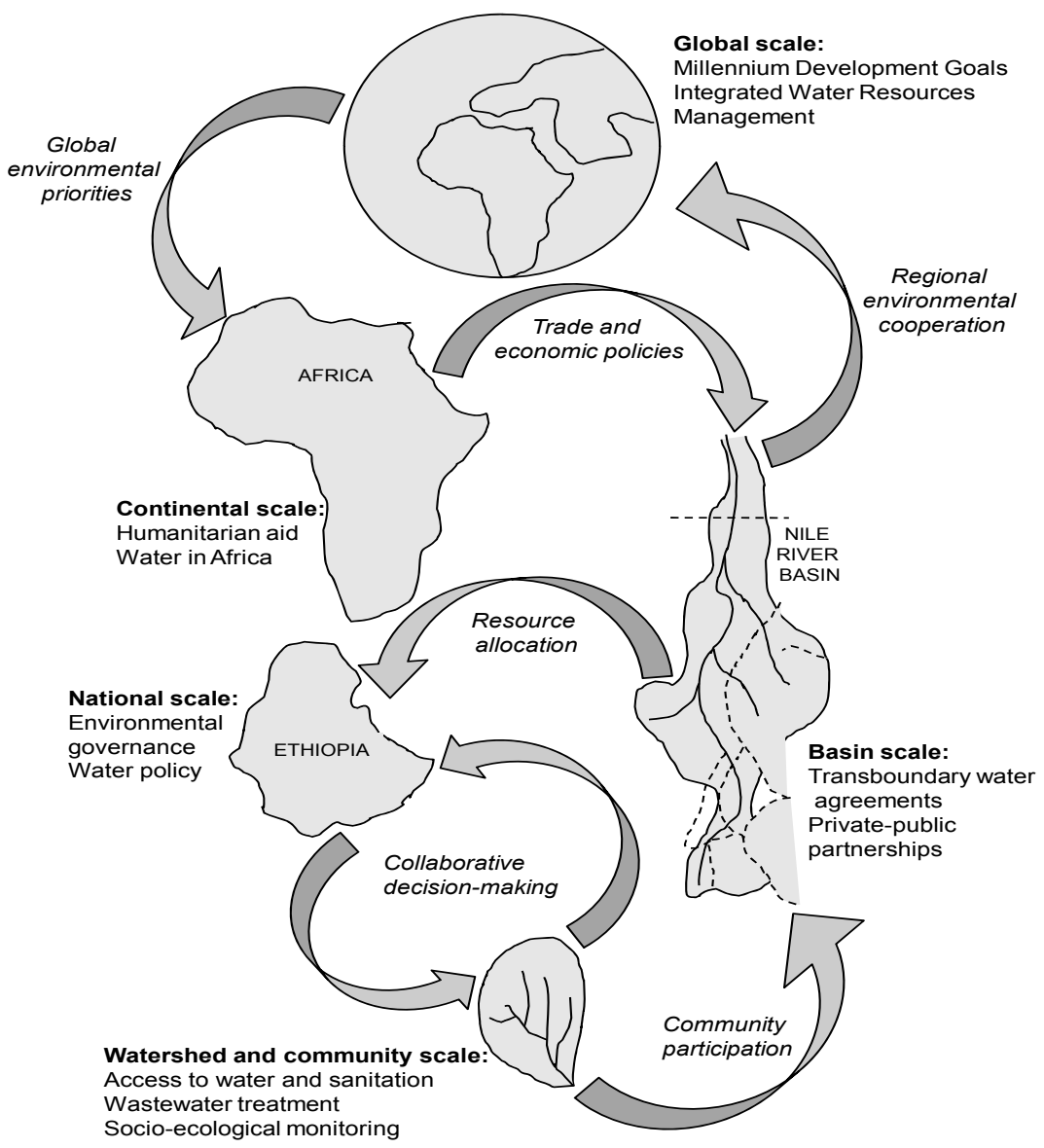

Figure 2: A nested spatial hierarchy and water resource activity. At each level some of the considerations relating to water issues are indicated. The arrows represent some examples of relations between levels in the hierarchy. 


\section{Conclusion: preliminary results}

The 2008 Report to Congress, as required by the WfP Act, identifies several priority countries by region (Table 1) [27]. These countries define the regional boundaries to implement key objectives, strategies, and approaches related to water-related initiatives. For example, sub-Saharan Africa, Asia and the Pacific are regions that host several different local and regional projects. Within subSaharan Africa some projects are included: Sustainable Water and Sanitation for Africa (SUWASA) that targets 15 sub-Saharan countries, the West African Water Initiative (WAWI) established in Ghana, Niger, and Mali, Okavango Transboundary Watershed Management Program in southwestern Africa, and a water, sanitation, and hygiene movement (WASH) in central Ethiopia. In Asia and the Pacific, projects are focused on USAID's ECO-Asia Program (Environmental Cooperation). ECO-Asia projects include regions such as Surabaya and Bandung, Indonesia, Negombo, Sri Lanka, and Marikina, Philippines and activities in several other countries.

Table 1: $\quad$ US priority countries for 2008 .

\begin{tabular}{|c|c|c|c|c|}
\hline Region & $\begin{array}{l}\text { Area } \\
(\mathrm{million} \\
\left.\mathrm{mi}^{2}\right)\end{array}$ & $\begin{array}{l}\text { Population } \\
\text { (in millions) }\end{array}$ & $\begin{array}{l}\text { Access to } \\
\text { water }(\%)\end{array}$ & $\begin{array}{l}\text { Sanitation } \\
(\%)\end{array}$ \\
\hline Sub-Saharan Africa & 5.7 & 566.1 & 50 & 35 \\
\hline \multicolumn{5}{|c|}{$\begin{array}{l}\text { DR of Congo, Ethiopia, Ghana, Kenya, Liberia, Madagascar, Mali, } \\
\text { Mozambique, Niger, Nigeria, Senegal, Somalia, Sudan, Tanzania, Uganda, } \\
\text { Zambia }\end{array}$} \\
\hline Asia and the Pacific & 209 & 1,800 & 84 & 42 \\
\hline \multicolumn{5}{|c|}{$\begin{array}{l}\text { Bangladesh, Cambodia, India, Indonesia, Laos, Pakistan, Philippines, Sri } \\
\text { Lanka, Tajiskistan, Timor-Leste, Vietnam }\end{array}$} \\
\hline Europe and Eurasia & .04 & 9.6 & 87 & 88 \\
\hline \multicolumn{5}{|c|}{ Armenia, Georgia, Kosovo } \\
\hline $\begin{array}{l}\text { Latin America and } \\
\text { the Caribbean }\end{array}$ & .01 & 8.5 & 54 & 30 \\
\hline \multicolumn{5}{|l|}{ Haiti } \\
\hline Middle East & .596 & 115.8 & 94 & 94 \\
\hline
\end{tabular}

Source: Paul Simon Water for the Poor Act 2008 Report to Congress, http://www.state.gov/g/oes/rls/rpts/105543.htm

These projects are based on watersheds, regions, municipalities, and rural villages. Data remains sketchy and there are few maps available at the appropriate scale. Defining the spatial parameters of these projects - areas impacted that include not only demographics, but also the associated environments, ecosystems, and water systems are needed in order to begin the process of spatial analysis. A few of the key issues of creating a GIS for developing countries is the problem of data availability, accessibility, and data at 
the appropriate scale. Our efforts are focused on country wide efforts where UN data provides the basis for a regional analysis.

Important to this assessment is setting the historical context with respect to water governance. Understanding the historical setting of developing countries is critical to determining if successful water safety and sanitation can be developed. Strengthening social rights and identifying the common good of water provisioning were keys to the near universal coverage accomplished in developed countries. Recognition that the poorest members of society need different arrangements that do not fit into the dominant market-based strategies is required to identify new solutions [26]. Including these aspects within our geospatial analysis will broaden the current context for water access and sanitation. Identifying spatial linkages between social justice, water access, and community participation will identify new spaces and scales for activism and education.

\section{References}

[1] U.S. Senate, $109^{\text {th }}$ Congress, Senator Paul Simon Water for the Poor Act of 2005, http://www.wilsoncenter.org/events/docs/WFPA\%20-\%20LAW.pdf

[2] Gerlak, A. K., Federalism and U.S. water policy: lessons for the twentyfirst Century, Journal of Federalism, 36(2), pp. 231-257, 2005.

[3] Henninger, N. \& Hammond, A., Environmental Indicators Relevant to Poverty Reduction. A Strategy for the World Bank, World Resources Institute: Washington, D.C., 2000.

[4] Dasgupta, S., Deichmann, U., Meisner, C. \& Wheeler, D., Where is the Poverty-Environment Nexus? Evidence from Cambodia, Lao PDR, and Vietnam. World Development, 33(4), pp. 617-638, 2005.

[5] Conca, K., The United States and International Water Policy, Journal of Environment and Development, 17(3), pp. 215-237, 2008.

[6] Hargrove, W.L., Garrity, D.P., Rhoades R.E \& Neely, C.L., A Landscape/Lifescape Approach to Sustainability in the Tropics: The Experience of the SANREM CRSP at Three Sites, (Chapter 13). Integrated Watershed Management in the Global Ecosystem. ed., R. Lal. CRC Press: Boca Raton, pp. 209-222, 2000.

[7] Deutsch, W.G., Busby, A.L. Orprecio, J.L. Bago-Labis, J.P. \& Cequina, E.Y., Community-based hydrological and water quality assessments in Mindanao, Philippines, (Chapter 9). Forests, Water and People in the Humid Tropics. eds., M. Bonell \& L.A. Bruijnzeel, Cambridge University Press: Cambridge, pp. 134-149, 2005.

[8] United Nations Office of the High Commissioner for Human Rights (UN OHCHR), www.unhchr.ch/development/poverty-02.html

[9] The Universal Declaration of Human Rights, http://www.un.org/en/documents/udhr/).

[10] Langford, M., The United Nations concept of water as a human right: a new paradigm for old problems? International Journal of Water Resources Development, 21(2), pp. 273-282, 2005. 
[11] World Summit on Sustainable Development (WSSD), Plan of Implementation, 2002.

[12] United Nations Millennium Development Goals UUN MDGs), www.un.org/milleniumgoals/environ.shtml

[13] Kashyap, A., Water governance: learning by developing adaptive capacity to incorporate climate variability and change, Water Science and Technology, 49(7), pp. 141-146, 2004.

[14] Shyamsundar, P., Poverty - Environment Indicators. Environmental Economic Series - Paper No. 84, World Bank: Washington, D.C., 2002.

[15] Al-Jayyousi, O., Water as a human right: towards civil society globalization, International Journal of Water Resources Development, 23(2), pp. 329-339, 2007.

[16] Anand, P. B., Right to water and access to water: an assessment, Journal of International Development, 19(4), pp. 511-526, 2007.

[17] Irujo, A. E., The Right to Water, International Journal of Water Resources Development, 23(2), pp. 267-283, 2007.

[18] Laban, P., Accountability and rights in a right-based approaches for local water governance, International Journal of Water Resources Development, 23(2), pp. 355-367, 2007.

[19] Centre for Strategic and International Studies \& Sandia National Laboratories (CSIS-SNL), Global Water Futures: Addressing our global water future. CSIS: Washington, D.C., 2005.

[20] Ostrum, E., Governing the Commons: Evolution of Institutions for Collective Action, Cambridge University Press: New York, 1990.

[21] Ostrum, E., Dietz, T., Dolsak, N., Stern, P.C., Stonich, S. \& Weber, E.U., (eds). The Drama of the Commons, National Academy Press: Washington, D.C., 2002.

[22] Berkes, F., From community-based resource management to complex systems: The scale issue and marine commons, Ecology and Society, 11(1), 45, http://www.ecologyandsociety.org/vol11/iss1/art45/, 2006.

[23] Imperial, M. T., Using Collaboration as a Governance Strategy: Lessons from Six Watershed Management Programs, Administration \& Society, 37(3), pp. 281-320, 2005.

[24] Environmental Governance Working Group (EGWG), The Landscape of Environmental Governance Research. Discussion Paper 1, Colorado State University: Fort Collins, 2009.

[25] Peterson, E. R. \& Posner, R. Global water futures: A roadmap for future U.S. Policy. Centre for Strategic and International Studies Press: Washington, D.C., pp. 1-57, 2008.

[26] World Health Organization \& UNICEF, Meeting the MDG drinking water and sanitation target: the urban and rural challenge of the decade, WHO Press: Geneva, 2006.

[27] Castro, J.E., Poverty and citizenship: Sociological perspectives on water services and public-private participation, Geoforum, 38, pp. 756-771, 2007. 
[28] U.S. Department of State, Senator Paul Simon Water for the Poor Act 2005 Report to Congress, Bureau of Oceans and International Environmental Scientific Affairs: Washington, D.C, 2008.

[29] U.S. Agency for International Development (USAID) Environment, Washington, D.C., 2007, http://www.usaid.gov/our_work/environment/ water/iwrm_dvlpmt.html

[30] U.S. Department of State, Senator Paul Simon Water for the Poor Act 2005 Report to Congress Annex D, Bureau of Oceans and International Environmental Scientific Affairs: Washington, D.C, 2006.

[31] Patton, M. Q., Quantitative Evaluation and Research Methods, Sage Publications Newbury Park, 1990.

[32] Campbell, D. T. \& Fiske, D. W., Convergent and Discriminant Validation by the Multitrait-Multimethod Matrix (Chapter 2). Methodology and Epistemology for Social Science: Selected Papers, eds. S. E. Overman, \& D. T. Campbell, University of Chicago Press: Chicago, pp. 37-61, 1988.

[33] Lal, R., (ed). Integrated Watershed Management in the Global Ecosystem, CRC Press Boca Raton, 2000.

[34] Brooks, K. N., Ffolliott, P. F., Gregersen, H. M. \& DeBano, L. F., Hydrology and the Management of Watersheds. Iowa State University Press: Ames, 2003.

[35] Norman, E. \& Baker, K., Transgressing scales: water governance across the Canada-US borderland, Annals of the Association of American Geographers, 99(1), pp.99-117, 2009.

[36] Zimmerer, K., Overlapping patchworks of mountain agriculture in Peru and Bolivia: toward a regional-global landscape model, Human Ecology 27(1) pp. 135-165, 1999. 